\title{
CHARACTERIZATION AND DYNAMICS OF SURFACE FUEL OF CERRADO GRASSLAND IN JALAPÃO REGION - TOCANTINS, BRAZIL
}

\author{
Micael Moreira Santos ${ }^{1 *}$, Antonio Carlos Batista ${ }^{2}$, Allan Deyvid Pereira da Silva ${ }^{2}$, Eduardo Ganassoli Neto ${ }^{1}$, Ana \\ Carolina Sena Barradas ${ }^{3}$, Marcos Giongo ${ }^{1}$ \\ ${ }^{1}$ Universidade Federal do Tocantins, Centro de Monitoramento Ambiental e Manejo do Fogo - CeMAF, Gurupi, Tocantins, Brasil - \\ moreirasmicael@gmail.com; eduardo.florestal@uft.edu.br; giongo@uft.edu.br \\ ${ }^{2}$ Universidade Federal do Paraná, Laboratório de Incêndios Florestais, Curitiba, Paraná, Brasil - batistaufpr@gmail.com; \\ allanuft@gmail.com \\ ${ }^{3}$ Instituto Chico Mendes de Conservação da Biodiversidade - ICMBio, Rio da Conceição, Tocantins, Brasil - carolbarradas@gmail.com
}

Received for publication: 14/06/2019 - Accepted for publication: 03/10/2019

\begin{abstract}
Resumo
Caracterização e dinâmica de combustível superficial de cerrado campestre na região do Jalapão - Tocantins, Brasil. O presente estudo teve como objetivo avaliar as características do combustível superficial, durante a estação seca, em áreas com diferentes períodos sem ocorrência de queima, localizadas em fitofísionomia campestre de Cerrado na região do Jalapão. Para isso, foram realizadas coletas de material combustível em áreas com diferentes períodos sem ocorrência de queima, no decorrer de quatro meses da estação seca (maio, junho, agosto e setembro). Foram estabelecidas 128 amostras denominadas de unidade de amostragem de dados, na qual, foram realizadas coletas de oito subamostragens designadas de parcelas de material combustível. Em cada parcela de material combustível foram amostradas variáveis pelo método não destrutivo, tais como, a altura da vegetação herbácea (Htg), altura da manta (Htl), quantidade de espécies (Nsp) e quantidade de indivíduos (Nin), além de variáveis amostradas pelo método destrutivo para obtenção de carga. A separação do combustível foi feita de acordo com o seu estado fisiológico e as diferentes classes de diâmetro (time-lag). A variável Htg atingiu seu maior porte e se estabilizou já no segundo ano pós-ocorrência de queima e quanto ao Nsp observou-se redução na quantidade das áreas com quatro anos sem queima e no último mês da estação seca. O comportamento da carga do combustível herbáceo morto $(\mathrm{Dg})$, em coletas realizadas nos dois primeiros meses da estação seca, foi o único que corroborou com a hipótese de diferentes incrementos nos diferentes anos sem queima. Os resultados obtidos são de grande relevância para as ações de manejo do combustível campestre, realizado na região do Jalapão.

Palavras-chave: Carga de combustível; Manejo do fogo; Estação seca, Idade do combustível; Classes do combustível; Biomassa de gramíneas.
\end{abstract}

Abstract
The aim of the present study was to evaluate the characteristics of surface fuel during the dry season in areas
with different periods without occurrence of burn, in the grasslands phytophysiognomy of the Cerrado in the
Jalapão region of Brazil. Fuel sampling was conducted in areas with different periods without burning over
four months during the dry season (May, June, August, and September). A total of 128 samples, named as data
samples, were established, from which eight subsamples designated as parcels of fuel sampling were collected.
In each parcel of fuel sample, we evaluated variables related to non-destructive methods such as the height of
grass vegetation (Htg), litter height (Htl), number of species (Nsp), and number of individuals (Nin), as well as
variables related to the destructive method for obtaining the fuel load. The fuel was separated according to its
physiological state and diameter (time-lag). The Htg variable was highest and was stabilized by the second year
post-burning. Nsp showed a reduced number of areas after four years without burning and in the last month of
the dry season. The behavior of the dead grass fuel (Dg) load in the samplings collected in the first two months
of the dry season was the only variable that increased in the different years without burning. These results are
important for management initiatives of Cerrado grassland fuels in the Jalapão region.
Keywords: Fuel load; Fire management; Dry season; Fuel age; Fuel classes; Grassland biomass.

\section{INTRODUCTION}

Although fuel is very important for the occurrence and propagation of forest fires, fuel characteristics are seasonal and complex (RICCARDI et al., 2007, KEANE, 2013). The characteristics of fuel determine the intensity, propagation, duration, and size of forest fires and are directly related to the quantity and changes of emission patterns of gas produced by fires (GOULD et al., 2011).

Riccardi et al. (2007) reported the importance of understanding fuel characteristics to access carbon stock information, while Stephens et al. (2012) highlighted that determining characteristics such as the fuel accumulation rate are very important for understanding the effectiveness of reduction measures for the fuel load. However, because of the long time required and high costs involved, studies aimed at evaluating the physical characteristics of surface fuel and its seasonal variability in the Cerrado of Brazil are extremely scarce.

FLORESTA, Curitiba, PR, v. 51, n. 1, p. 127-136, jan/mar 2021

Santos, M. M et.al.

ISSN eletrônico 1982-4688

DOI: 10.5380/rf.v51 i1. 67440 
Surface fuel, which represents the portion of biomass located vertically up to $2 \mathrm{~m}$ above the mineral soil (KEANE, 2013), is divided into the following components: duff and litter, downed and dead woody biomass in a range of diameter classes (time-lag of 1, 10, 100, and $1000 \mathrm{~h}$ ), and shrub and grass vegetation which is classified into live and dead fuel. Additionally, fuel can be described according to its physical attributes such as load, depth, height, density, and moisture content (SCHROEDER; BUCK, 1970).

Some studies have evaluated the spatial variability of fuel characteristics, different structures and their respective loads, as well as their influence on fire behavior. Other studies, such as those by Duff et al. (2012) and Parresol et al. (2012), evaluated the relationships between composition and fuel load. Additionally, other studies aimed to develop models for predicting the rate of distribution, behavior of parameters according to the age of fuel (GOULD et al., 2011), and surface fuel load of different components into distinct classes (BATTAGLIA et al., 2010, LYDERSEN et al., 2015).

In one of the few studies conducted in the Cerrado savanna environment, Hoffmann et al. (2012) quantified the relative importance of fuel characteristics and the microclimate to determine changes in fire behavior; they found that greater flammability was related to the presence of grass vegetation. Castro e Kauffman (1998) determined the biomass and root mass gradients for different Cerrado phytophysiognomies, both pre and post-fire. Pivello et al. (2010) evaluated the effects of fire on different fire regimes in Cerrado dry grasslands (campo sujo) over 18 years and the composition of fine fuel, while Conceição e Pivello (2011) quantified plant biomass in dry grasslands two years after burning.

Studies involving the quantification of fuel and other characteristics post-disturbance, after burning or forest fires, and the dynamics for different months of the year are fundamental for implementing effective fire management strategies (BATTAGLIA et al., 2010, KEANE, 2013). Understanding these dynamics in grasslands phytophysiognomies in the Cerrado (particularly campo limpo and campo sujo), which greatly influences occurrence of forest fires, is practically null (CASTRO; KAUFFMAN, 1998). The only study that assessed the behavior of fire in wet grasslands (campos úmidos) vegetation in different seasons and in areas with different years since the last burn was done by Schmidt et al. (2017).

The objective of the present study was to evaluate the characteristics of surface fuel during the dry season in areas in which burning had not occurred for different periods in a grasslands phytophysiognomy of Cerrado in the Jalapão region of Brazil. The study assumed the following hypotheses: (i) the characteristics of fuel in its different physiological states and classes, as well as in specific periods without occurrence of fire, differ because of the accumulation of fuel generated over time; and (ii) fuel characteristics may vary during different periods of the dry season because of variabilities in air temperature and relative humidity.

\section{MATERIAL AND METHODS}

\section{Study area}

The study was conducted in an area of the Serra Geral do Tocantins Ecological Station (EESGT), a protected area, located in the Cerrado biome in the Jalapão region with an area of 716.306 hectares (ha). The EESGT stretches through the municipalities of Almas, Mateiros, Ponte Alta, and Rio da Conceição (Tocantins State in Brazil), as well as the municipality of Formosa do Rio Preto (Bahia State in Brazil). According to the Köppen-Geiger climate classification, the region's climate is type Aw (equatorial savannah with dry winter) with strong annual precipitation that is greater than potential annual evapotranspiration. The rainy season occurs between the months of October to April, while the dry season occurs between May and September. The predominant Cerrado phytophysiognomy is grassland type including the dry grasslands ("campo limpo seco," "campo sujo seco," and "campo rupestre") in addition to wet grasslands ("campo limpo úmido" and "campo sujo úmido") (RIBEIRO; WALTER, 2008). The predominant soil type is quartz sands or quartzarenic neosol, which has a sandy texture at a dept of at least $2 \mathrm{~m}$ and is composed of up to $15 \%$ of clay. The relief is relatively flat and gently undulated, with average altitude between 300 and $550 \mathrm{~m}$ (SANTOS et al., 2013).

\section{Treatments and procedures for determining fuel variables}

The study treatments were based on the sampling of fuel over four months during the dry season (May, June, August, and September) in areas with different periods without burning (PWB). Due to fire management activities, the predominant grassland areas in the EESGT range 1 to 4 years without burning, but there are some locations in which have longer periods without burning. These areas were verified to have different PWB using remote sensing techniques by analyzing burns scars throughout the dry season. Such information, are institutional data produced by EESGT management. Therefore, during the experiment, 128 plots, named as a unit of data sampling, were done, being of these, 32 plots collected in each one of 4 months of the study (32 units of data sampling $\times 4$ months). Of these 32 units of data sampling, 8 were distributed in areas with PWB from 1, 2, 3, and 4 years $(8$ units of data sampling $\times 4$ PWB).

Each unit of data sampling (plot) had two $30-\mathrm{m}$ transects, where 8 sub-repetitions of $0.25 \mathrm{~m}^{2}$, designated

FLORESTA, Curitiba, PR, v. 51, n. 1, p. 127-136, jan/mar 2021.

Santos, M. M et.al.

ISSN eletrônico 1982-4688

DOI: $10.5380 /$ rf.v51 i1. 67440 
as fuel sampling plot, were randomly distributed. Therefore, given that 8 fuel sampling plots were collected for each unit of data sampling, a total of 1,024 fuel sampling plots were collected ( 8 fuel sampling plots $\times 128$ units of data sampling). The original fuel load values were converted into $\mathrm{Mg} \mathrm{ha}^{-1}$ for each data sample unit. The species and their individual numbers were determined in terms of the original sample size $\left(0.25 \mathrm{~m}^{2}\right)$. Appropriate calculations were performed for the sample sufficiency knowledge.

Prior to sampling by the destructive method, grass height (Htg in centimeters - $\mathrm{cm}$ ) and litter height (Htl, in $\mathrm{cm}$ ) were measured, with two measurements performed for each variable in the sample. Additionally, the number of species (Nsp) and number of individuals (Nin) in each $0.25-\mathrm{m}^{2}$ sample were verified. It is noteworthy that such variables (Nsp and Nin) were obtained only from the above-ground plants, not considering root physiologic state of the plant. During the four months of fuel sampling in the dry season, the air temperature in degrees Celsius and relative humidity as a percentage were recorded by a portable weather station (Kestrel 4200, Kestrel Pocket Weather Meters, Boothwyn, PA, USA).

Fuel sampling to determine load was performed in a destructive manner, separating the material according to its physiological stage (live or dead), by diameter class (time-lag) as described by Schroeder e Buck (1970), and also separating the grass fuel of this classes. Live fuel was classified as follows: (i) live grass fuel (Lg); (ii) 1-h live fuel; (iii) 10-h live fuel; and (iv) 100-h live fuel. Similarly, dead combustible fuel was classified as follows: (i) dead grass fuel (Dg); (ii) 1-h dead fuel; (iii) 10-h dead fuel and; (iv) 100-h dead fuel. However, the load values for the classes 10-h live fuel, 100-h live fuel, 10-h dead fuel, and 100-h dead fuel were not considered because they showed insignificant quantities compared to the others, preventing statistical analyses. Additionally, total live fuel $(\mathrm{Tl})$ and dead fuel $(\mathrm{Td})$, and total fuel load $(\mathrm{Tl}+\mathrm{Td})$ in different periods without burning and different months of fuel sampling were determined.

A subsample for each fuel class was placed in a kraft paper bag, numbered, and had their mass determined using a digital scale. Then, the subsamples were dried in the laboratory oven until reach constant weight for subsequent determination of the fuel's dry mass and moisture content.

\section{Statistical analysis}

To analyze the values for fuel load and variables obtained by the non-destructive method, analysis of factorial variance was performed for the four periods without burning and four months of fuel sampling in a completely randomized design. To compared the average values, the Tukey test at 5\% significance was performed, while logarithmic transformations and the squared root for the Htl, Nin, Lg, 1-h live fuel, Dg, 1-h dead fuel, Tl, and $\mathrm{Td}$ variables and Total $(\mathrm{Tl}+\mathrm{Td})$ were performed to meet the premises of normality and homoscedasticity.

The values obtained in the study are presented in boxplots, where the limits of the boxes represent the lower (25\%) and upper quartiles (75\%), inner lines represent the median values, and outer lines correspond to the maximum and minimum values. For values reflecting the MFS vs. PWB interaction at 5\% significance (Htg, $\mathrm{Htl}$, Nsp, Lg, Dg, 1-h dead fuel, Td, and Total), the graphs were presented to show the interaction of each PWB in each MFS and vice-versa. The values for Nin, 1-h live fuel, and Tl were not statistically evaluated, as they did not show an MFS vs. PWB interaction. Principal component analysis was also performed based on a correlation matrix.

\section{RESULTS}

\section{Fuel moisture}

The average and standard deviation values for the moisture of the fuel in different classes are presented in Table 1, considering the distinct PWBs and MFSs, and their differences at 5\% significance by Tukey test. When considering the moisture of the fuel in different PWBs, in some cases, significant greater values for fuel moisture were observed in areas with a longer PWB. Thus, the PWB is not the variable that best responds to variations in fuel moisture content. Considering the seasonal variability, higher values of fuel moisture were measured in months of May and June and lower in August and September $(\mathrm{p}<0.05)$.

Table 1. Averages and standard deviation of fuel moisture by fuel type considering variations in different periods without burning and different months of fuel sampling.

Tabela 1. Médias e desvio padrão da umidade do combustível por tipo considerando as variações nos diferentes períodos sem queima e os diferentes meses de coleta do combustível.

\begin{tabular}{lllll}
\hline \multirow{2}{*}{ Fuel type } & \multicolumn{4}{c}{ Period without burning } \\
\cline { 2 - 5 } & 1 year & 2 years & 3 years & 4 years \\
\hline Live grass & $57.9^{\mathrm{b}}(11.4)$ & $56.2^{\mathrm{b}}(12.2)$ & $59.7^{\mathrm{ab}}(9.1)$ & $66.4^{\mathrm{a}}(12.7)$ \\
1-h live fuel & $93.2^{\mathrm{ab}}(16.4)$ & $85.0^{\mathrm{c}}(13.8)$ & $87.7^{\mathrm{bc}}(10.1)$ & $99.1^{\mathrm{a}}(13.8)$ \\
Dead grass & $9.1^{\mathrm{ab}}(8.8)$ & $10.1^{\mathrm{ab}}(5.2)$ & $8.7^{\mathrm{b}}(3.8)$ & $11.1^{\mathrm{a}}(3.6)$ \\
1-h dead fuel & $7.1^{\mathrm{b}}(4.9)$ & $8.0^{\mathrm{ab}}(4.7)$ & $7.8^{\mathrm{ab}}(3.9)$ & $9.4^{\mathrm{a}}(3.2)$ \\
\hline Fuel type & \multicolumn{5}{c}{ Month of fuel sampling } \\
\hline
\end{tabular}

Fuel type




\begin{tabular}{lllll}
\hline & May & June & August & September \\
\hline Live grass & $66.6^{\mathrm{a}}(11.8)$ & $63.8^{\mathrm{a}}(10.7)$ & $54.4^{\mathrm{b}}(8.7)$ & $55.4^{\mathrm{b}}(12.0)$ \\
1-h live fuel & $98.6^{\mathrm{a}}(12.6)$ & $98.3^{\mathrm{a}}(11.2)$ & $88.2^{\mathrm{b}}(11.9)$ & $79.9^{\mathrm{c}}(14.1)$ \\
Dead grass & $12.1^{\mathrm{a}}(6.8)$ & $11.7^{\mathrm{ab}}(6.2)$ & $8.2^{\mathrm{bc}}(4.0)$ & $7.2^{\mathrm{c}}(3.8)$ \\
1-h dead fuel & $8.4^{\mathrm{ab}}(4.4)$ & $10.7^{\mathrm{a}}(3.9)$ & $7.4^{\mathrm{bc}}(3.2)$ & $5.9^{\mathrm{c}}(4.2)$ \\
\hline
\end{tabular}

Legend: Means followed by the same letters did not differ from each other by the Tukey test at a $\%$ probability level. Values in parentheses indicate standard deviation.

The average air temperature and relative humidity for each month of fuel sampling obtained at the time of fuel sampling are presented in Table 2 . The relative humidity decreased from $41.0 \%$ in the first month of fuel sampling (May) to $27.3 \%$ in the last month (September), and the air temperature changed from 30.3 to $31.0{ }^{\circ} \mathrm{C}$, respectively. No rainfall was registered from the months of May to September, however, it should be noted that the number of days without rainfall is greater as the months pass, until the end of the dry season.

Table 2. Averages of air temperature $\left({ }^{\circ} \mathrm{C}\right)$ and relative humidity $(\%)$ during fuel sampling.

Tabela 2. Médias de temperatura $\left({ }^{\circ} \mathrm{C}\right)$ e umidade relativa do ar $(\%)$ durante a amostragem de material combustível.

\begin{tabular}{lllll}
\hline \multirow{2}{*}{ Meteorologic variables } & \multicolumn{3}{c}{ Months of fuel sampling } \\
\cline { 2 - 5 } & May & June & August & September \\
\hline Averages of air temperature $\left({ }^{\circ} \mathrm{C}\right)$ & $30.3^{\mathrm{a}}(2.6)$ & $27.4^{\mathrm{b}}(3.4)$ & $29.5^{\mathrm{ab}}(3.8)$ & $31.0^{\mathrm{a}}(3.1)$ \\
Averages of relative humidity $(\%)$ & $41.0^{\mathrm{a}}(11.7)$ & $38.4^{\mathrm{a}}(9.3)$ & $29.6^{\mathrm{b}}(10.1)$ & $27.3^{\mathrm{b}}(9.2)$ \\
\hline
\end{tabular}

Legend: Means followed by the same letters did not differ from each other in the Tukey test at the 5\% probability level. Values in parentheses indicate the standard deviation.

The influence of relative humidity in relation to the fuel moisture variation over the dry season months was observed, showing a correlation of $\mathrm{r}=0.98(\mathrm{p}<0.05)$. While the correlation between air temperature and fuel moisture was not significant of $r=-0.57$.

\section{Statistical analysis of averages of surface fuel variables}

The height of grass plants (Htg), as presented in Figure 1a, had a $16.43 \%$ coefficient of variation (CV) and values varying from 13.4 to $49.1 \mathrm{~cm}$. Higher average values were observed in the final month of fuel sampling (September) in an area presenting three years without burning (PWB 3 in September $=35.3 \mathrm{~cm}$ ), with lower values observed in the same month of fuel sampling in a location with one year after burning (PWB 1 in September = $18.4 \mathrm{~cm}$ ). Analysis of the MFS vs. PWB interaction revealed that among the different periods without the occurrence of burning, Htg values increasing in the first year (PWB 1) in nearly all months of fuel sampling, up until the fourth year without burning (PWB 4), showing no significant difference by Tukey test $(p>0.05)$ beginning in the second year. An exception was found for sampling in September in areas of four years without burning (PWB 4 in September), where values were lower compared to in areas without burning of 2 and 3 years; the values were only greater than in areas of 1 year without burning $(\mathrm{p}<0.05)$.

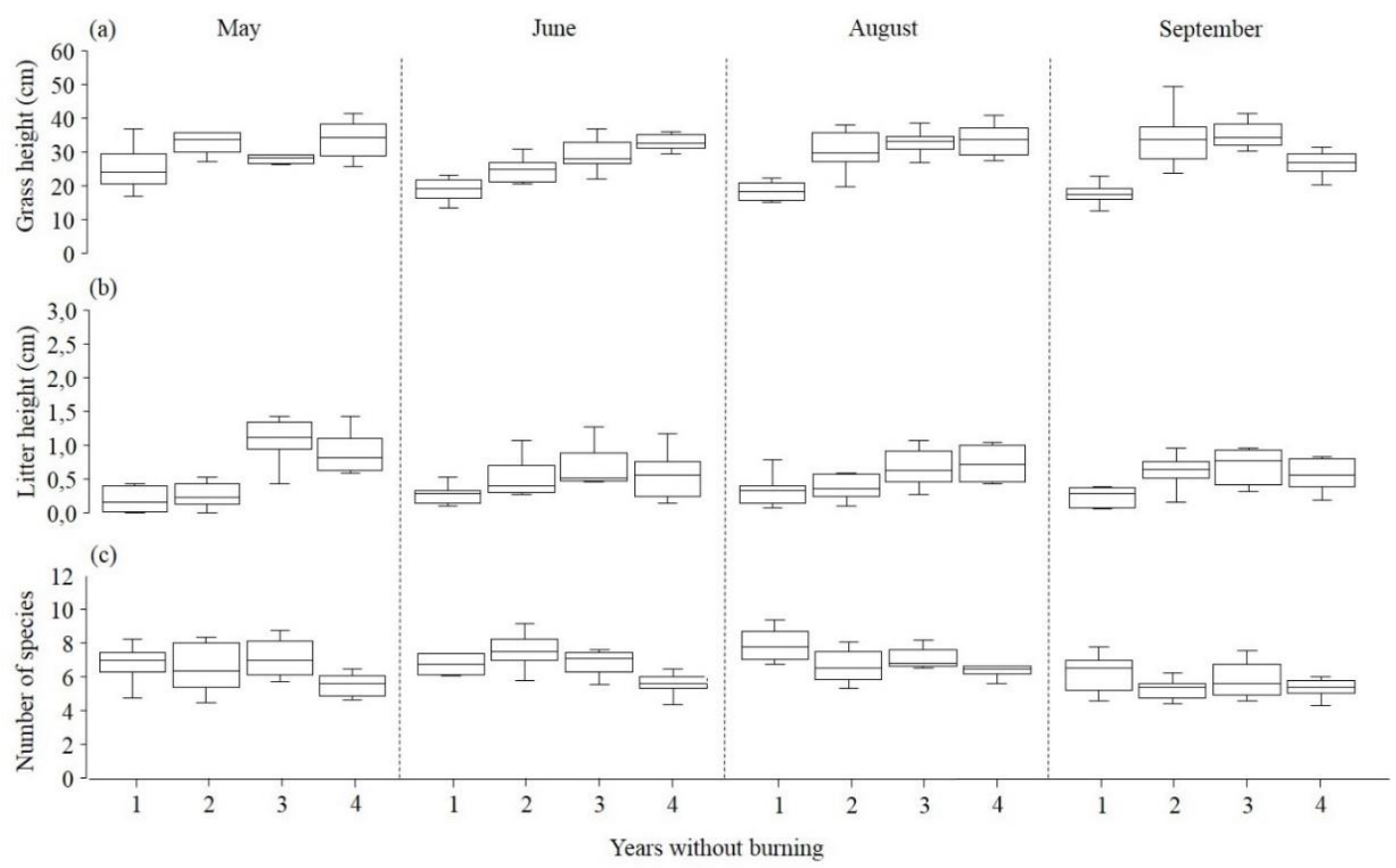

FLORESTA, Curitiba, PR, v. 51, n. 1, p. 127-136, jan/mar 2021. 
Figure 1. Boxplots representing interactions between fuel variables obtained by the non-destructive method. (a) Grass height in cm, (b) Litter height in cm, and (c) Number of species.

Figura 1. Boxplots representando as interações entre as variáveis de combustível obtidas pelo método não destrutivo. (a) Altura das gramíneas em cm, (b) Altura da manta em cm, e (c) Número de espécies.

Litter height $(\mathrm{Htl} ; \mathrm{CV}=28.11 \%)$ values varied from 0.0 to $2.8 \mathrm{~cm}$ (Figure $1 \mathrm{~b})$, with the highest averages observed in the first month of fuel sampling (May) in the area of three years without burning (PWB 3 in May = $1.1 \mathrm{~cm})$ and lowest values in areas with 1 year without burning $(0.2 \mathrm{~cm})$. For the MFS vs. PWB interaction, only fuels sampled in June did not show a significant difference compared to the other sampling months in which increased Htl values were observed. Considering the first sampling month (May), the Htl values in areas of 3 and 4 years without burning were greater and for fuel sampling in August and September, only areas with a period without burning of 1 year showed lower values compared to the others areas according to Tukey test $(p<0.05)$.

The number of species ( $\mathrm{Nsp} ; \mathrm{CV}=13.21 \%$ ), which is presented in Figure 1c, varied from approximately 4 to 9 species in $0.25 \mathrm{~m}^{2}\left(\mathrm{sp} / 0.25 \mathrm{~m}^{2}\right)$, with the average number of species higher in the month of August in locations at 1 year post-burning (PWB 1 in August with $\left.\approx 8 \mathrm{sp} / 0.25 \mathrm{~m}^{2}\right)$ and lower in September $\left(\approx 6 \mathrm{sp} / 0.25 \mathrm{~m}^{2}\right)$; no significant difference between periods without burning were observed. For the MFS vs. PWB interaction, a significant decrease in the number of species was observed in the $1^{\text {st }}, 2^{\text {nd }}$, and $3^{\text {rd }}$ sampling months (May, June, and August) only in areas with 4 years without burning. In the last sampling month (September), differences between the PWBs were not observed. However, the number of above-ground species was decreased compared to in the other months of fuel sampling.

Fuel load values, live grass fuel $(\mathrm{Lg} ; \mathrm{CV}=7.00 \%)$ varied from 0.19 to $1.97 \mathrm{Mg} \mathrm{ha}^{-1}$, with the average loads for this fuel type greater in May in areas of 1 year without burning (PWB 1 in May $=1.49 \mathrm{Mg} \mathrm{ha}^{-1}$ ) and lower in September in locations of four years without burning (PWB in September $=0.39 \mathrm{Mg} \mathrm{ha}^{-1}$ ), as shown in Figure 2a. For the MFS vs. PWB interaction, a reduction in load values in areas with periods without burning of 3 and 4 years was observed in May and September; this relationship differed compared to those in areas with 1 and 2 years without burning, which showed significantly higher fuel load values. In August, the values were only higher in the areas at 1 year post-burning.

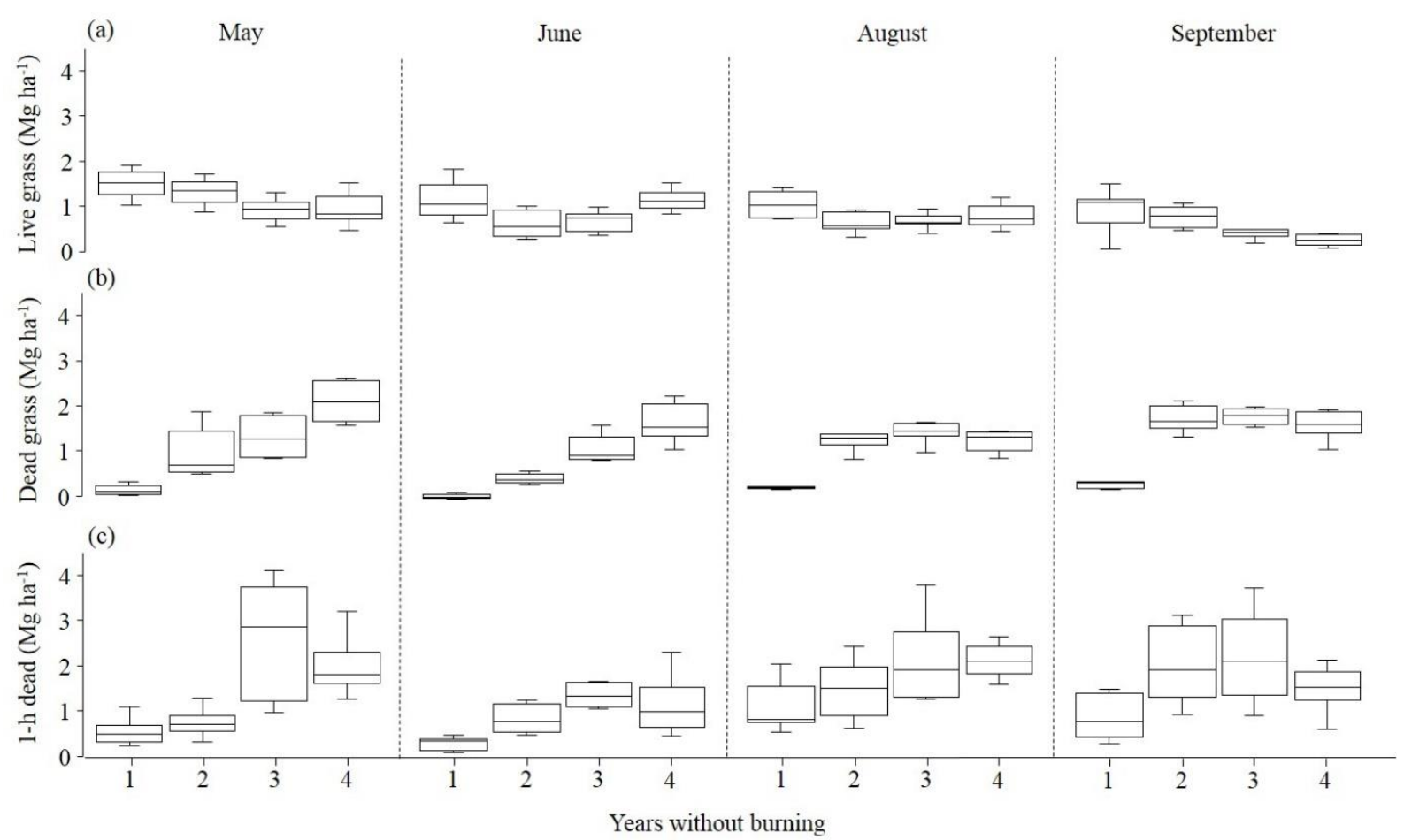

Figure 2. Boxplots representing interactions between fuel variables obtained by the destructive method (fuel load). (a) Live grass fuel load in $\mathrm{Mg} \mathrm{ha}^{-1}$, (b) Dead grass fuel load in $\mathrm{Mg} \mathrm{ha}^{-1}$, and (c) 1-h dead fuel load in $\mathrm{Mg}$ $\mathrm{ha}^{-1}$.

Figura 2. Boxplots representando as interações entre as variáveis de combustível obtidas pelo método destrutivo (carga de combustível). (a) Carga de combustível vivo de gramíneas em $\mathrm{Mg} \mathrm{ha}^{-1}$, (b) Carga de combustível morto de gramíneas em $\mathrm{Mg} \mathrm{ha}^{-1}$, e (c) Carga de combustível lenhoso de 1-h em $\mathrm{Mg} \mathrm{ha}^{-1}$.

FLORESTA, Curitiba, PR, v. 51, n. 1, p. 127-136, jan/mar 2021. 
The dead grass fuel load ( $\mathrm{Dg} ; \mathrm{CV}=7.62 \%$ ) varied from 0.0 to $2.8 \mathrm{Mg}^{-1}$ (Figure $2 \mathrm{~b}$ ). The average Dg values were higher in the first sampling month during the dry season in areas presenting four years without burning $\left(\mathrm{PWB} 4 \mathrm{in}\right.$ May $\left.=2.10 \mathrm{Mg} \mathrm{ha}^{-1}\right)$ and lower in June in areas with 1 year without burning $\left(0.07 \mathrm{Mg} \mathrm{ha}^{-1}\right)$. In the MFS vs. PWB interaction, in the first two months of fuel sampling (May and June), all PWBs differed from one another. Therefore, fuel accumulation during the first two months of the dry season differed in each year without burning. In August and September, in areas with periods without burning of more than 2 years, the averages did not differ from one another, with only the areas with 1 year without burning showing lower dead grass fuel load values.

The 1 -h dead fuel values $(\mathrm{CV}=27.07 \%)$ varied from 0.17 to $4.1 \mathrm{Mg} \mathrm{ha}^{-1}$ (Figure $2 \mathrm{c}$ ), with the highest average values found in May in areas presenting three years without burning (PWB 3 in May $=2.62 \mathrm{Mg} \mathrm{ha}^{-1}$ ) and lowest in June in locations with one year without burning (PWB 1 in June $=0.37 \mathrm{Mg} \mathrm{ha}^{-1}$ ). The results were similar in June, August, and September, (considering the MFS vs. PWB interaction), in which the 1-h dead fuel load did not differ between the areas with 2, 3, and 4 years post-burning greater values observed than in areas at one year without burning. An exception was observed in the first month of fuel sampling, with no difference between locations with periods of 1 and 2 years without burning (lower) and between PWBs of 3 and 4 years, which were significantly higher.

The total dead fuel ( $\mathrm{Td} ; \mathrm{CV}=10.80 \%$ ) varied from 0.18 to $6.76 \mathrm{Mg} \mathrm{ha}^{-1}$, with the highest average values observed in May in areas presenting 4 years of fuel accumulation post-burning (PWB 4 in May $=4.31 \mathrm{Mg} \mathrm{ha}^{-1}$ ) and lower in June in areas with one year without burning (PWB 1 in June $=0.45 \mathrm{Mg} \mathrm{ha}^{-1}$ ) (Figure 3a). Based on the MFS vs. PWB interaction, similar behaviors were observed in May and June, between the periods of 3 and 4 years (higher; $p<0.05$ ) and a significant difference was observed between locations with periods without burning of 1 and of 2 years. In the third and fourth months of fuel sampling (August and September), a difference was only detected in locations at 1 year post-burning compared to the other areas with 2, 3, and 4 years, which were higher according to the Tukey test.

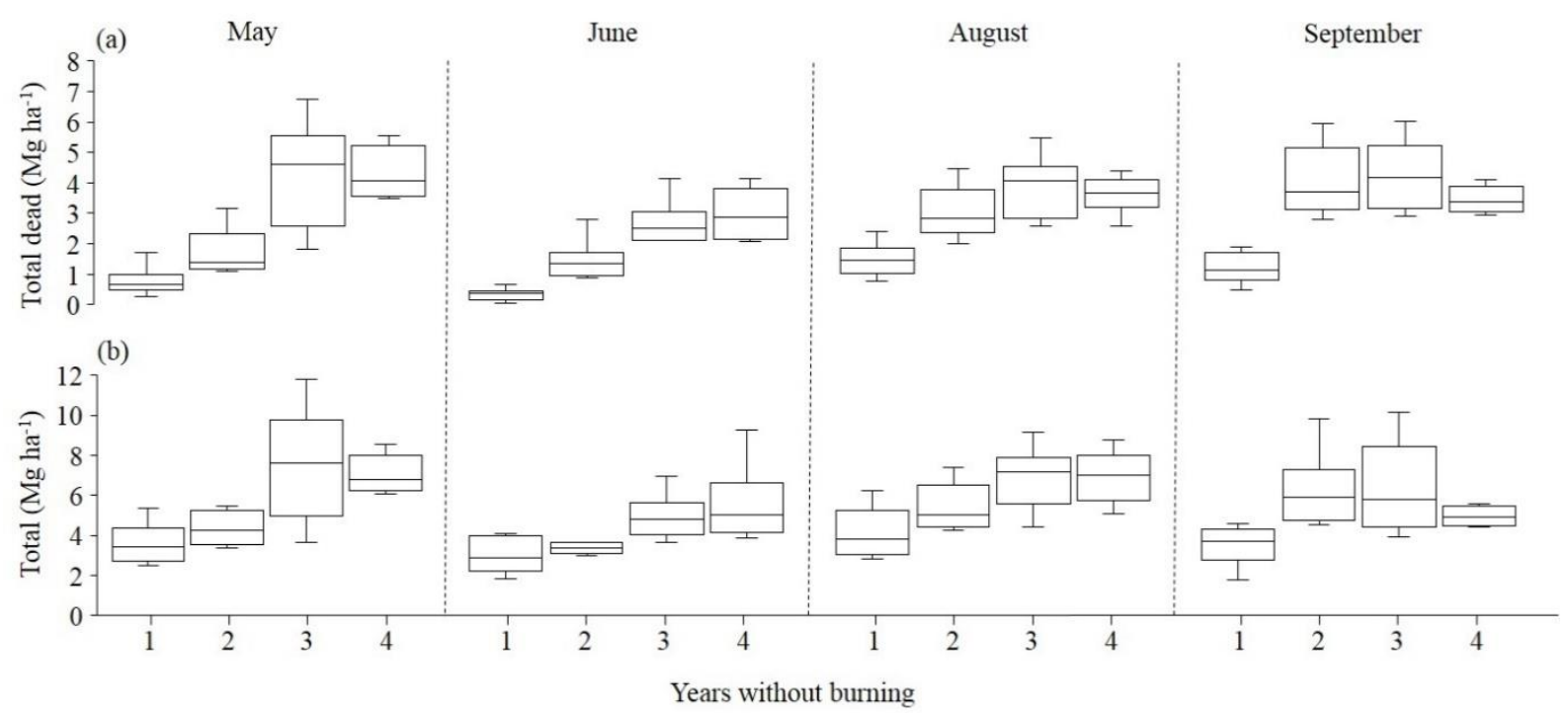

Figure 3. Boxplots representing interactions between variables of total fuels. (a) Total dead fuel load in $\mathrm{Mg} \mathrm{ha}^{-1}$, and (b) Total fuel load in $\mathrm{Mg} \mathrm{ha}^{-1}$.

Figura 3. Boxplots representando a interação entre as variáveis de combustível total. (a) Carga de combustível total morto em $\mathrm{Mg} \mathrm{ha}^{-1}$, e (b) Carga de combustível total em $\mathrm{Mg} \mathrm{ha}^{-1}$.

The total fuel load $(\mathrm{CV}=12.34 \%)$ ranged from 1.93 to $11.77 \mathrm{Mg} \mathrm{ha}^{-1}$, with the highest averages observed in the first month of fuel sampling (May) in locations presenting 3 years without burning (PWB 3 in May $=7.54$ $\mathrm{Mg} \mathrm{ha}^{-1}$ ) and lower in the second month (June) in areas with 1 year without burning (PWB 1 in June $=3.06 \mathrm{Mg}$ $\mathrm{ha}^{-1}$ ). For the MFS vs. PWB interaction, the values in the areas with 1 and 2 years without burning in May and June were lower than in the others (periods with 3 and 4 years) and those in August and September only in areas with 1 year without burning were significantly lower, which was similar to the results for dead grass fuel, 1-h dead fuel, and total dead fuel (Figure 3b).

\section{Principal component analysis}

In principal component analysis of the average values for factors representing the months of fuel sampling and periods without burning (Figure 4), component 1 explained $41.41 \%$ of the variation through the variables Htg, 
Htl, Dg, 1-h dead fuel, and Td; component 2 explained $22.84 \%$ of the variation with the variables Nsp and Nin; and component 3 explained $13.99 \%$ of the variation with the variables $\mathrm{Lg}, 1-\mathrm{h}$ live fuel, and $\mathrm{Tl}$.

In the first biplot (Figure 4a), higher values for the factors that representing the first component (axis $x$ ) were represented by later sampling months in areas with longer periods without burning. For component 2 (axis $y$ ), represented by the variables Nsp and Nin, higher values (positive) for the $y$ coordinates of the graph were observed with greater frequency in the initial sampling months of the dry season in areas presenting shorter periods of disturbance after burning. These results confirm that a longer time after the occurrence of fire, particularly in areas with 4 years, and later sampling of fuel was associated with a smaller number of species (Nsp) and total number of individuals (Nin) in the area.
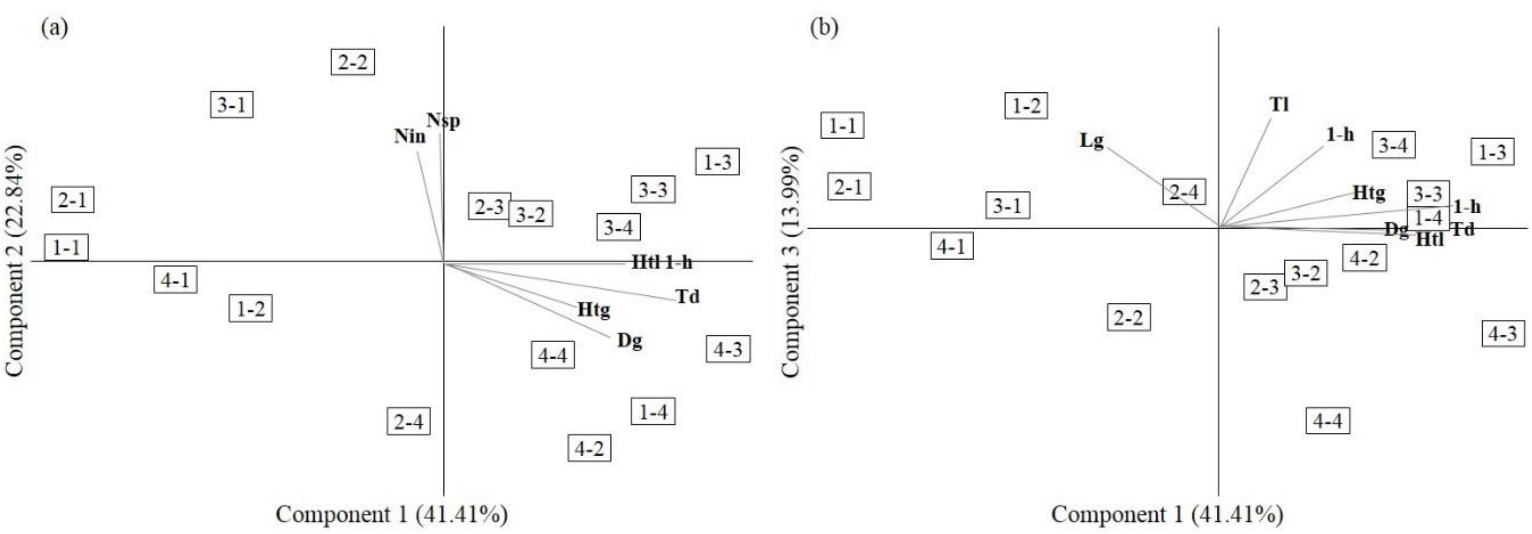

Figure 4. Biplots related to principal component analysis using fuel variables (destructive and non-destructive method). (a) Representation of components 1 (x-axis) and 2 (y-axis), (b) Representation of components 1 (x-axis) and 3 (y-axis). The study treatments are presented inside the boxes in the following order: MFS - PWB.

Figura 4. Biplots relacionado à análise dos componentes principais utilizando as variáveis de material combustível (métodos destrutivo e não destrutivo). (a) Representação do componente 1 (eixo x) e 2 (eixo y), (b) Representação do componente 1 (eixo x) e 3 (eixo y). Os tratamentos do estudo são demonstrados dentro das caixas na seguinte ordem: MFS - PWB.

In the second biplot (Figure 4b), for the third component (axis y), whose variables were live fuel (Lg, 1$\mathrm{h}$ live fuel, $\mathrm{Tl}$ ), the positive values were more strongly associated with fuel collected at the start of the dry season and with shorter periods without the occurrence of fire, confirming the analyses results of the fuel load averages.

\section{DISCUSSION}

The behavior of fuel moisture content for the different periods without burning, as shown in Table 1, can be explained by the fact that in locations with longer periods without disturbance by fire, fuel moisture is higher because of the greater vegetation coverage. In areas with sparser vegetation because of more recent fires, the fuel moisture content is generally lower (LINDENMAYER et al., 2009, CAWSON et al., 2017). Studies in Cerrado grassland vegetation investigating fuel moisture at different times of the burning need to be carried out in greater numbers to better understand this behavior.

As expected, the behavior of moisture content during the different months of fuel sampling was directly related to the change of meteorological conditions throughout the dry season, mainly at the beginning and end of the season (Table 1), highlighting the influence of air relative humidity on fuel moisture $(\mathrm{r}=0.98 ; \mathrm{p}<0.05)$. According to Chuvieco et al. (2002), the moisture content of live fuel is influenced by the interaction of the plant's physiology and soil humidity conditions, while the humidity of dead fuel is more strongly related to local meteorological factors. Additionally, Bowyer e Danson (2004) described the influence of the deeper roots of shrubby vegetation, which have better access to subsoil moisture, which is not observed for grass vegetation.

The grassy vegetation that predominates in the area, generally reaches its full size by the second year of development and maintains this size in subsequent years (Figure 1a). The variable litter height (Figure 1b) behaved similarly to the 1-h dead fuel class $(\mathrm{Htl})$. It was not possible to differentiate the Htl of areas with post-fire periods longer than 2 years in the last months of fuel sampling (August and September). Thus, the senescence of shrub individuals in the area showed behaviors similar to those in locations with periods without burning of 2 years in the periods of dry season. Because this study was done in a grassland area (campo sujo and campo limpo), the

FLORESTA, Curitiba, PR, v. 51, n. 1, p. 127-136, jan/mar 2021.

Santos, M. M et.al.

ISSN eletrônico 1982-4688

DOI: $10.5380 /$ rf.v51 i1. 67440 
litter height is much lower than that of forest areas. Proof of this can be observed in studies of Hoffman et al. (2012) that shows a litter height of $6.3 \mathrm{~cm}$ in Pinus stands in Arizona state, while Beutling et al. (2012) found average values of $9.4 \mathrm{~cm}$ in Pinus forests.

In terms of the Nsp shown in Figure 1c, two distinct behaviors were observed, with one related to a decreased Nsp in areas with 4 years without burning and the other related to a decreased Nsp in all periods without burning in the last month of the dry season (September). The first is likely related to the incapacity of certain pioneering species of a shrub-herbaceous character to regenerate because of the natural competition that occurs over time, leading to the mortality of shade-intolerant species (SOARES et al., 2017). The second behavior may be associated with the adaptations of certain species to the more adverse weather conditions, as well as fire tolerance capacity, in which only aerial part of the plant fades away in the dry season. Some Cerrado species may present underground xylopodia or lignotubers that maintain the plant alive underground during the dry season and regrowth aerial part in the rainy season (SIMON et al., 2009). In September, Nsp values were similar to each other independently of the period without burning in the area.

Lg decreased as the period without burning increased (Figure 2a), which can be explained by the fact that the predominant grass vegetation in the Cerrado grassland area in the Jalapão region are pioneering species; these species cannot regenerate their own shading (SOARES et al., 2017).

The behavior of the Dg in May and June was the only factor that agreed with the hypothesis regarding the occurrence of different levels of increase of the fuel load during specific PWBs (Figure 2b). Dg responded better to variability in the PWBs possibly because fine fuel, which shows a stronger response to meteorological changes (GANTEAUME et al., 2013), is the predominant fuel type in both quantity and longevity throughout the dry season (CAWSON et al., 2017). In the first months of the dry season (May and June), the weather conditions are not extreme (high air temperatures and low relative humidity); however, the last two sampling months (August and September), corresponding to the final period, are characterized by the highest air temperatures and lowest relative humidity levels (Table 2). Thus, in the third and fourth months, Dg increased similarly in areas with periods of 2, 3, and 4 years without burning; thus, the response of Dg to more adverse conditions during the dry season led to similar fuel loads in locations with two or more years without burning.

The 1-h dead fuel class, in contrast to Dg, showed different accumulations of load according to period post-burning in the first two months of fuel sampling and did not respond variably according to the period without burning. Beginning in June, the areas with periods without burning above 2 years showed statistically similar increases (Figure 2c). This shows that the deposit of woody debris and senescence of shrub individuals in grassland areas of the Cerrado were relatively unresponsive to variations in the different periods without the occurrence of burning. However, an increased load of this class (1-h dead fuel) during the last two months of the dry season (August and September) was observed.

For the behavior of Td, as shown in Figure 3a, a tendency similar to that of 1-h dead fuel was observed. This behavior may be related to its larger load (mass of 1-h dead fuel) compared to Dg, which, despite the smaller mass, presents greater continuity in the Cerrado grassland areas with finer materials, and thus shows a better surface-volume relationship between its leaves. Such characteristic allows for the faster exchange of humidity and absorption of heat, making it a more flammable material than 1-h dead fuel (GANTEAUME et al., 2013). In a study of the importance of fuel characteristics, Hoffmann et al. (2012) observed greater flammability of savanna because of the presence of grass vegetation. Cawson et al. (2017) found that the quantity of fine fuel with low moisture levels influences the quantity of fuel available for burning, leading to greater ignitability, higher rates of fire propagation, and higher intensity of forest fires.

The dynamic of the total load of the Cerrado grassland fuel (campo sujo) in the study area during the dry season, shown in Figure 3b, followed the same trend as dead fuel, with no differences in areas with 2-4 years and during the last two months of the dry season. Schmidt et al. (2017) evaluated the Jalapão region in wet grasslands vegetation (campos úmidos), and also observed no differences between the load of the areas burnt for 2 and 5 years. Despite the difference in behavior in the vegetation studied, behaviors similar to those detected in the present study with values stabilizing starting in the second year without burning were observed.

Hoffmann et al. (2012) observed a total load value of $7.6 \mathrm{Mg} \mathrm{ha}^{-1}$ for fuel in savanna in Cerrado, while Castro e Kauffman (1998) observed values of $9.3 \mathrm{Mg} \mathrm{ha}^{-1}$ in Cerrado dry grasslands (campo sujo). Conceição e Pivello (2011) observed a load of $4.9 \mathrm{Mg} \mathrm{ha}^{-1}$ in clean field vegetation. The differences in loads between similar phytophysiognomies may be related to the distinct climate characteristics, soil variability, and altitude, among other factors, observed in the Cerrado, and, as observed in this study, due to the different periods without burning. Thus, it is difficult to make generalizations regarding this biome (CASTRO; KAUFFMAN, 1998).

The variables Nin, 1-h live fuel, and Tl did not present an MFS vs. PWB interaction, which may be related to the non-significant variation in the live woody fuel load in different months of the dry season and in areas with different periods without the occurrence of burning. The loads of these types of fuel did not vary significantly between the different situations analyzed.

FLORESTA, Curitiba, PR, v. 51, n. 1, p. 127-136, jan/mar 2021

Santos, M. M et.al.

ISSN eletrônico 1982-4688

DOI: $10.5380 /$ rf.v51 i1. 67440 


\section{CONCLUSIONS}

- It was only possible to statistically distinguish different increases of fuel load in areas at 1-4 without burning for the Dg collected in the first two months of the dry season (May and June). In the last two months (August and September), the fuel load remained constant in areas with 2-4 years without burning, revealing differences in the accumulation dynamics for fuel during the dry season. These results are important for fuel management initiatives in Cerrado grassland areas.

- In addition to dead grass fuel, significant similarities were observed between the remaining dead fuel variables, such as dead wood material of 1-h, total dead fuel, and total fuel, as well as the litter height variable, in the areas of 2, 3, and 4 years without burning in fuels sampled in the two final months of the dry season (August and September).

- Htg present in the Cerrado grassland areas was highest in the second year after burning and stabilized at 2,3 , and 4 years after burning.

- Nsp decreased in two different manners, showing a decrease in areas with 4 years without the occurrence of burning and for sampled fuels in the final month of the dry season (September).

\section{ACKNOWLEDGEMENTS}

To Federal University of Tocantins (Brazil). This study was financed in part by the Coordenação de Aperfeiçoamento de Pessoal de Nível Superior - Brasil (CAPES) - Finance Code 88887.334846/2019-00. To managers of Serra Geral do Tocantins Ecological Station, Ana Carolina Sena Barradas, Marco Assis Borges and Máximo Menezes Costa, for the support in the planning and logistic of field collections.

\section{REFERENCES}

BATTAGLIA, M.A.; ROCCA, M.E.; RHOADES, C.C.; RYAN, M.G. Surface fuel loadings within mulching treatments in Colorado coniferous forests. Forest Ecology and Management, v.260, p.1557-1566, 2010.

BEUTLING, A.; BATISTA, A.C.; STOLLE, L.; TETTO, A.F.; ALVES, M.V.G. Caracterização e modelagem de material combustível superficial em povoamentos de Pinus elliottii. Revista Floresta, Curitiba, v.42, n.3, p.443452, 2012.

BOWYER, P.; DANSON, F.M. Estimating live fuel moisture content from remotely sensed reflectance. Remote Sensing of Environment, v.92, p.309-321, 2004.

CASTRO, E.A.; KAUFFMAN, J.B. Ecosystem structure in the Brazilian Cerrado: a vegetation gradient of aboveground biomass, root mass and consumption by fire. Journal of Tropical Ecology, v.14, p.263-283, 1998.

CAWSON, J.G.; DUFF, T.J.; TOLHURST, K.G.; BAILLIE, C.C.; PENMAN, T.D. Fuel moisture in Mountain Ash forests with contrasting fire histories. Forest Ecology and Management, v.400, p.568-577, 2017.

CHUVIECO, E.; RIANO, D.; AGUADO, I.; COCERO, D. Estimation of fuel moisture content from multitemporal analysis of Landsat Thematic Mapper reflectance data: Applications in fire danger assessment. International Journal of Remote Sensing, v.23, p.2145-2162, 2002.

CONCEIÇÃO, A.A.; PIVELLO. V.R. Biomassa combustível em Campo Sujo no entorno do Parque Nacional da Chapada Diamantina, Bahia, Brasil. Biodiversidade Brasileira, v.2, p.146-160, 2011.

DUFF, T.J.; BELL, T.L.; YORK, A. Predicting continuous variation in forest fuel load using biophysical models: a case study in south-eastern Australia. International Journal of Wildland Fire, v.22, p.318-332, 2012.

GANTEAUME, A.; JAPPIOT, M.; LAMPIN, C.; GUIJARRO, M.; HERNANDO, C. Flammability of Some Ornamental Species in Wildland-Urban Interfaces in Southeastern France: Laboratory Assessment at Particle Level. Environmental Management, v.52, p.467-480, 2013.

GOULD, J.S.; MCCAW, W.L.; CHENEY, N.P. Quantifying fine fuel dynamics and structure in dry eucalypt forest (Eucalyptus marginata) in Western Australia for fire management. Forest Ecology and Management, v.262, p.531-546, 2011.

HOFFMANN, W.A.; JACONIS, S.Y.; MCKINLEY, K.L.; GEIGER, E.L.; GOTSCH, S.G.; FRANCO, A.C. Fuels or microclimate? Understanding the drivers of fire feedbacks at savanna-forest boundaries. Austral Ecology, v.37, p.634-643, 2012.

HOFFMAN, C.M.; SIEG, C.H.; MCMILLIN, J.D.; FULE, P.Z. Fuel loadings 5 years after a bark beetle outbreak

FLORESTA, Curitiba, PR, v. 51, n. 1, p. 127-136, jan/mar 2021

Santos, M. M et.al.

ISSN eletrônico $1982-4688$

DOI: $10.5380 /$ rf.v51 i1. 67440 
in south-western USA ponderosa pine forests. International Journal of Wildland Fire, v.21, p.306-312, 2012.

KEANE, R.E. Describing wildland surface fuel loading for fire management: a review of approaches, methods and systems. International Journal of Wildland Fire, v.22, p.51-62, 2013.

LINDENMAYER, D.B.; HUNTER, M.L.; BURTON, P.J.; GIBBONS, P. Effects of logging on fire regimes in moist forests. Conservation Letters, v.2, p.271-277, 2009.

LYDERSEN, J.M.; COLLINS, B.M.; KNAPP, E.E.; ROLLER, G.B.; STEPHENS, S. Relating fuel loads to overstorey structure and composition in a fire-excluded Sierra Nevada mixed conifer forest. International Journal of Wildland Fire, v.24, p.484-494, 2015.

PARRESOL, B.R.; BLAKE, J.I.; THOMPSON, A.J. Effects of overstory composition and prescribed fire on fuel loading across a heterogeneous managed landscape in the southeastern USA. Forest Ecology and Management, v.273, p.29-42, 2012.

PIVELLO, V.R.; OLIVERAS, I.; MIRANDA, H.S.; HARIDASAN, M.; SATO, M.N.; MEIRELLES, S.T. Effect of fires on soil nutrient availability in an open savana in Central Brazil. Plant Soil, v.337, p.111-123, 2010.

RIBEIRO, J.F; WALTER, B.M.T. As principais fitofisionomias do Bioma Cerrado. In.: SANO, S.M; ALMEIDA, S.P; RIBEIRO, J.F. Ecologia e flora. Brasília: EMBRAPA, v.1, p.152-212, 2008.

RICCARDI, C.L.; OTTMAR, R.D.; SANDBERG, D.V.; ANDREU, A.; ELMAN, E.; KOPPER, K.; LONG, J. The fuelbed: a key element of the fuel characteristic classification systems. Canadian Journal of Forest Research, v.37, p.2394-2412, 2007.

SANTOS, R.P.; CREMA, A.; SZMUCHROWSKI, M.A.; POSSAPP, J.J.; NOGUEIRA, C.C.; ASANO, K.; KAWAGUCHI, M.; DINO, K. Atlas do corredor ecológico da região do Jalapão. 2. ed. Brasília: Instituto Chico Mendes de Conservação da Biodiversidade, 2013. 85 p.

SCHROEDER, M.J.; BUCK, C.C. Fire weather: a guide for application of meteorological information to forest fire control operations. Washington, D.C., US Dep. Agric. 1970, 229 p.

SCHMIDT, I.B., FIDELIS, A., MIRANDA, H.S.; TICKTIN, T. How do the wets burn? Fire behavior and intensity in wet grasslands in the Brazilian savana. Brazilian Journal of Botany, v.40, p.167-175, 2017.

SIMON, M.F.; GRETHER, R.; QUEIROZ, L.P.; SKEMA, C.; PENNINGTON, R.T.; HUGHES, C.E. Recent assembly of the Cerrado, a neotropical plant diversity hotspot, by in situ evolution of adaptations to fire. Procedings of the National Academy of Sciences of the United Sates of America, v.106, n.48, p.20359-20364, 2009.

SOARES, R.V.; BATISTA, A.C.; TETTO, A.F. Incêndios florestais: controle, efeitos e uso do fogo. 2. ed. rev. Curitiba: 2017.255 p.

STEPHENS, S.L; COLLINS, B.M; ROLLER, G. Fuel treatment longevity in a Sierra Nevada mixed conifer forest. Forest Ecology and Management, v.285, p.204-212, 2012. 